\title{
El poder de las imágenes o Atenea pateada
}

Keywords: derecho; legislación; jurisprudencia; animal

Durante algunos días circuló por la red un video en el que un sujeto torturaba de forma cruel a unos cachorros hasta matarlos. No ahorraba ningún detalle del crimen que estaba cometiendo y se atrevía incluso a indicar el lugar donde vivía (supuestamente en Extremadura) y los datos para identificarle. Como si quisiera retar a los defensores de la ley a seguirle la pista. Una continuación del juego macabro iniciado con la difusión de unas imágenes cruentas, fruto del dolor de unos pobres cachorros confiados, que, posiblemente, hasta que no sintieron que los mutilaban creyeron que iban a iniciar una forma distinta de divertirse, mirando felices, moviendo las colas sin parar.

La reacción de muchos ciudadanos fue advertir de la existencia de ese video y alertar a la policía de que iniciara la búsqueda del maltratador, autotitulado "Knino". Se recogieron firmas de mucha gente. Se llegó incluso a articular una plataforma para iniciar una acción popular contra el desalmado. No se pudo impedir, en cambio, que el video se pasara por algunas cadenas de televisión, para ilustrar la noticia. Algunos cambiamos de canal, pero estoy segura de que las imágenes tuvieron una amplia difusión; me consta por los comentarios de amigos, conocidos y compañeros.

No es tolerable que imágenes de violencia contra animales se difundan sin ningún tipo de control ni de regulación. Hace pocos años, nos dejaron impactados, a mucha gente, las imágenes y los gemidos de dolor de un perro, que, atado a las puertas de un cobertizo, era apaleado sin piedad por su dueño, retransmitidas por muchas televisiones en horario en el que, también niños, pueden estar delante de la televisión. Es decir, los informativos de las cadenas que suele emitirse entre las 20,30 y las 22,00h ¿Qué hace reaccionar a la gente?. ¿La violencia visible y audible, o, por el contrario, la emisión de imágenes respetuosas con los animales?. La duda no es banal.

De hecho, no existe ningún Código ético, de aplicación general y de amplio consenso, respecto al tratamiento que los medios de comunicación deben dar a los animales. No resulta extraño, por ello que imágenes de violencia contra animales se difundan sin ningún tipo de control, salvo el que la opinión de los ciudadanos, que protestan, ejerce. A veces, demasiado tarde, pues las imágenes ya han sido difundidas.

Lo mismo cabe decir de las imágenes difundidas también por las cadenas televisivas, de la patada seca propinada por un jugador de fútbol a un búho, la mascota de los rivales que vivía en el propio campo, y que cayó al terreno de juego, atontado, después de haber recibido un balonazo. Los servicios veterinarios no pudieron hacer nada por salvar la vida del pequeño animal. En varias cadenas televisivas se pasó -y se repitió- el instante de la certera patada del jugador sobre el cuerpo indefenso del ave, que no podía volar. Los comentarios de los reporteros no denotaban censura por el acto de violencia, simplemente se recreaban en repetir y repetir la escena del la patada al "búho-balón-no-reglamentario". Fuera de todo reglamento, no consta tampoco que el cuerpo arbitral impusiera una sanción o reprimenda al autor de los hechos. El acto de violencia, presuntamente punible, ha recibido la reacción en contra de los foros de opinión, tanto en Latinoamérica, donde ocurrieron los hechos, como alrededor del mundo; basta echar un vistazo en Internet. Va a resultar que la vida de verdad, la que reacciona y se muestra contraria a la violencia y proclive a la defensa de los animales, esa vida es virtual. Va a resultar que el símbolo de la sabiduría, la encarnación de la propia diosa Atenea, el búho, símbolo también del pensamiento filosófico, yace hoy en día indefenso por los suelos y se le patea sin piedad. 
Por lo tanto, una primera idea, es poner de manifiesto una carencia ética de nuestros medios de comunicación; una segunda idea, es reiterar la necesidad de que los animales, su entorno y su idiosincrasia se respeten debidamente en las informaciones e imágenes que de ellos se difunden; una tercera idea, es reconocer y regular adecuadamente que las imágenes de violencia contra los animales, son tan perniciosas para la infancia como las escenas de crímenes de sangre, las palizas o las armas. La violencia, se ejerza contra quien se ejerza, sólo engendra más violencia.

LA EDITORA

Teresa Giménez-Candela Catedrática de Derecho Romano Animal Law Profesor Universitat Autònoma de Barcelona 